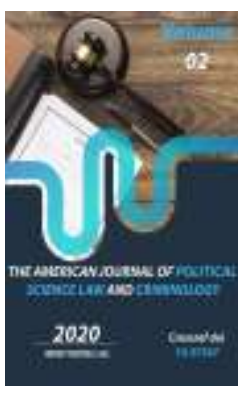

\title{
Religious Tolerance Is The Basis Of Society Sustainability And Integration
}

\author{
Dilnavoz Ozodovna Tojiboeva \\ Senior Lecturer, Department Of General Education, Tashkent State University Of Law, \\ Uzbekistan
}

Journal Website: http://usajournalshub.c om/index,php/tajpslc

Copyright: Original content from this work may be used under the terms of the creative commons attributes 4.0 licence.

\section{ABSTRACT}

The problem of religious tolerance is very significant for ensuring security in modern societies. Religious tolerance is the basis of social stability and integration. Intolerance to religious feelings and values led to bloody wars, division of states and nations. The article describes the principles and types of tolerance in world religions, values aimed at forming a culture of tolerance in the spiritual heritage of the Uzbek people.The issues of ensuring religious tolerance in the country, the activities of religious denominations and religious organizations and the formation of a culture of religious tolerance among young people are also covered.

\section{KEYWORDS}

Tolerance, religion, religious tolerance, stability, intolerance, security, religious organization, religiousconfessional groups, culture of tolerance, religious denomination, religious organization.

\section{INTRODUCTION}

The problem of religious tolerance has always been relevant for the countries of the world community. Since time immemorial, religion, if used correctly and wisely, has been a powerful unifying factor in society, and vice versa. Religions with good ideas have fostered qualities such as tolerance, peace, humanity, and friendship. The destructive actions in the name of religion and their teachings, on the contrary, caused instability in society. Unfortunately, indifference and intolerance to religious feelings and values of representatives 
of other religions also cause bloody wars, division of states and peoples in the modern world. In today's era of increasing globalization, it is important to highlight and inculcate the principles of tolerance in religions, especially world religions, in the minds of young people. Consequently, religious tolerance is the most effective factor in ensuring mutual understanding between different religions. Therefore, as stated in the Declaration of the Principles of Tolerance: "Without tolerance there will be no peace, and without peace there will be no progress and democracy"[1].

\section{THE MAIN FINDINGS AND RESULTS}

The concept of religious tolerance means that people of various faiths live together on the same land, in the same homeland, as partners and solidarity on the path of noble ideas and intentions. The concept of "tolerance" is one of the most widely used concepts in various fields of scientific activity and social life, including philosophy, political science, sociology, theology and religion. The term "religious tolerance" can be defined as follows: "This is the attitude of representatives of one religious denomination towards representatives of another religious denomination. Everyone has their own religious beliefs and recognizes that others have the same rights".

The Oxford Dictionary defines tolerance as "the willingness and ability of an individual to accept without objection or interference" [2].

Well-known Russian scientist V.A. Tishkov explains tolerance as follows: "Patience is a feature of openness and free thinking" [3]. This is a personal and social description, which means that the world and social environment are multifaceted, which means that views of the world are also diverse, they should not be forced to serve the same, someone's benefit.
The concept of tolerance in Uzbek has different meanings: endurance, patience, tolerance, tolerance, resilience, openness, generosity. Tolerance is a manifestation of human individuality, respect for different noble views, beliefs, multifaceted world culture and self-expression through correct understanding. Tolerance means the widespread implementation of the principle of "unity - diversity". Tolerance is becoming the norm for building civil society and an important value of today's civilization.

According to the classification given today by scientists of the concept of tolerance, they are divided into the following groups:

Political tolerance. It is the ability to tolerate the manifestation of different political views, opinions, convictions, aspirations, different from your own. Political tolerance is a certain order of political relations, an understanding of the need for cultural relations.

National-ethnic tolerance. This means that there is no negative attitude towards other national-ethnic cultures, but there is an assimilation of the positive aspects of the achievements of other cultures while maintaining important elements of their own culture. This is not the assimilation of one's own culture, but the process of enriching each other's national cultures as a result of nationalethnic integration.

The concept of religious tolerance means that people of different religions and denominations live side by side and in peace, despite the differences in beliefs.

Tolerance is divided into several types depending on which object it is manifested:

- $\quad$ Tolerance towards other religions (Islam - Christian, Islam - Buddhist, Christian - Buddhist); 
- Tolerance towards members of different denominations of the same religion (Sunni - Shia, Protestant Orthodox, Catholic - Orthodox);

- $\quad$ Tolerance towards different sects;

- Tolerance of believers towards atheists.

Misunderstandings and ignorance have led to mutual suspicion and mistrust in human life, which has led to various conflicts and bloody disagreements. How truthful was Abu Rayhan al-Biruni when he said: "People are hostile to what they do not know" [4]. The more objective and deeper the knowledge, the stronger the underlying values, values and worldview will be. In short, they define the possibilities of a culture of tolerance and become a strong shield against various manifestations of intolerance and intolerance. In particular, then the priority task is not to evaluate "others", their activities, "special" things and events only on the basis of their own values.

The values aimed at creating a culture of tolerance are deeply rooted in the spiritual heritage of the Uzbek people. Zoroastrianism, Judaism, Buddhism, Monism, Mazdakism, Christianity and other religions existed on the territory of modern Uzbekistan before the establishment of Islam. In the Indian and Persian territories of the country, the majority of people converted to Buddhism, while in Khorezm, Bukhara, Samarkand and Fergana, the population was predominantly Zoroastrian. In the pre-Islamic period, Buddhism was one of the most important components of ideological life in Central Asia. The spread of this doctrine dates back to the III-II centuries BC, the period of the Kushan Empire. The peoples of Central Asia who converted to Buddhism built special temples.
From the first centuries of our era, Jews with national religions began to appear in cities such as Samarkand and Bukhara. At the beginning of the 6th century a Nestorian bishop served in Samarkand and in the 8th century a Nestorian metropolitan. Even during Beruni's reign (9731048) there was an Orthodox metropolis in Merv. Christians also lived freely in Tashkent and Khorezm regions.

From the gth century onwards, the Hanafi sect, which is characterized by the tolerance of the Sunni branch of Islam towards other religions and local traditions, was established in the territory of our present homeland. The Hanafi school was more moderate in its treatment of Christians and Jews than any other school of Sharia, and the Imam Azam sect was also known for its tolerance of other religions. The ideas of tolerance, patience and religious tolerance were widely propagated in the works of great scholars who grew up in our country during this period. In particular, Abū Manșūr alMāturīdī, the founder of the Māturīdīyya creed, in his commentary on the verses of the Qur'an, in his commentary on verse 40 of Surat al-Hajj: "The demolition of churches and synagogues is prohibited. Therefore, in the land of the Muslims, they have remained intact until this time. There is no disagreement among the scholars on this issue "[5].

It is known from history that Amir Temur understood Islam as a universal faith, free from bigotry. His perfect faith was not at the expense of rejecting other religions, but also cared for members of other religions in his kingdom. This has earned Europe's deep respect. King Charles VI of France paid tribute to Amir Temur as follows: "We thank you, Your Excellency, for the respect, care and gifts that you have shown to many Christians. We are also ready to treat your people in a way that suits them or, if possible, more or less". 
Archbishop loann, Amir Temur's ambassador to Europe, describes Amir Temur's personality in his book "Memorire sur Tamer et sa cour": "Timur welcomes foreign traders, especially Franks and Christians, and provides them with security, care and assistance throughout the country" [6].

From the first years of independence of our country, the principle of respect for the religious feelings of the people, inter-religious tolerance has risen to a new level. "A Muslim child does not classify someone as a disbeliever or a pious person ... because it is God who rules over his servant, not his servant. Therefore, it is not right for us to accuse each other in vain and argue that I am a Muslim and you are a disbeliever", - said the First President of the Republic of Uzbekistan Islam Karimov [7].

Today, more than 90 percent of the country's population is Muslim, about 4 percent is Orthodox, and the rest are members of other denominations. As for religious organizations, almost 92 percent of religious organizations are Islamic religious organizations. In addition, there are more than 170 non-Islamic religious organizations, which are branches of religious organizations operating in various countries around the world.

In 1990, there were 119 religious organizations and 2 religious schools in the country, but today the number of religious organizations has reached 2,040. The largest of them are the Muslim Board of Uzbekistan, the Diocese of Tashkent and Central Asia of the Russian Orthodox Church, the Evangelical Baptist Church, the Roman Catholic Church, the Church of the Full Bible, the Bible Society of Uzbekistan and others. In addition, 2056 mosques, 157 Christian churches, 8 Jewish synagogues, 6 Baha'i societies, 1 Krishna Consciousness Society, 1 Buddhist temple and 1 biblical community have all the conditions for safe worship.

During the years of independence, hundreds of churches, synagogues and prayer houses have been built and renovated. These include the Orthodox Churches in Tashkent, Samarkand, Navoi, the Catholic Church in Tashkent, the Armenian Apostolic Church in Samarkand, and the Buddhist Church in Tashkent [8]. The newspaper "Word of life", the magazine "East from above", as well as prayer sermons and other enlightenment publications are published for the followers of the Orthodox faith in the republic.

The celebration of religious holidays is widespread in our country. The number of citizens going on Hajj, Umrah and other pilgrimages is also increasing year by year. It has become a good tradition for representatives of other religious communities to visit holy sites in Russia, Greece and Israel. The government provides the necessary support to pilgrims in various ways. On April 67, 2018, more than 130 Orthodox Christians visited Jerusalem.

In his speech at the 72nd session of the UN General Assembly, President of the Republic of Uzbekistan Shavkat Mirziyoyev appealed to the session participants with a proposal to adopt a special General Assembly resolution "Enlightenment and Religious Tolerance". The main purpose of this important document is to promote the right of everyone to a comprehensive education and to eradicate illiteracy and ignorance[9].

Shavkat Mirziyoyev stressed that the resolution should be aimed at promoting tolerance and mutual respect, ensuring religious freedom, protecting the rights of believers and preventing discrimination against them. The fifth direction of the Action Strategy for 2017-2021, approved by the Decree 
of the President of the Republic of Uzbekistan dated February 7, 2017, is security, aimed at ensuring interethnic harmony and religious tolerance, in which the study of the scientific heritage of great ancestors of the past will serve as an important factor in strengthening today's environment of peace and tolerance, preventing the spread of extremism and terrorism among young people.

\section{CONCLUSION}

The formation of a culture of religious tolerance in educational institutions and, in general, in all our youth is one of the most pressing issues of today. Accordingly, in this direction, in our opinion, the following tasks are required:

- Teaching the history of world religions in general education schools, academic lyceums and professional colleges, universities, their essence in accordance with the age, skills and desires of students, gradual mastering of topics, based on the principles of non-repetition;

- Explain to the younger generation the important role of religion in human and social life, that the faith of one or another representative of this religion will be further strengthened by respecting the beliefs of others;

- Coverage of the virtuous nature of all world religions, in particular Islam, in the media, on the Internet sites most often used by young people through concrete examples;

- Explain to the population that the evils of extremism, vandalism, violence, and evil are completely alien to religion, based on the materials of original and credible, tested sources;

- Achieving a clear and broad mastery of both knowledge to build the ability of citizens, especially young people, to distinguish between secular and religious issues.

\section{REFERENCES}

1. Declaration of Principles of Tolerance. // UNESCO International Normative Documents. Tashkent: “Adolat", 2004. -p. 92.

2. Oxford English Dictionary. Oxford University Press , 2005.

3. Tishkov V.A. Tolerance and consent in transforming societies // Tolerance and cultural tradition: collection of articles. Art. ed. M. Yu. Martynova. Moscow: RUDN, 2002.

4. Abu Rayhan Beruni. Tarvihalar. Tashkent: "Meros", 1991, -p. 38.

5. Ochildiev A. The essence and structure of a culture of tolerance. Tashkent: "Tashkent Islamic University", 2009.

6. Quronov M. The realization of good ideas. Tashkent: "Spirituality", 2011.

7. I.Karimov. The Way to Independence: Problems and Plans. Tashkent: “Uzbekistan", -p. 1992.

8. Kuchkarov R., Tadjibayeva D. The national idea: basic concepts and principles. T.TSU Publishing House, 2017.

9. http://uza.uz/oz/politics/zbekistonprezidenti-shavkat-mirziyeev-bmtbosh-assambleyasi-20-092017?sphrase_id $=2588615$ 